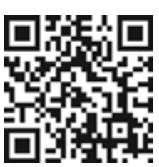

\title{
Evaluation of Paraoxonase 1 Activities in Patients Infected with Hepatitis C Virus Genotype 16 and Genotype 4 in the Kayseri Province of Turkey
}

\author{
Türkiye'nin Kayseri Bölgesindeki HCV Genotip 1b ve Genotip 4 ile Infekte Hastalarda \\ Paraoksonaz 1 Aktivitesinin Değerlendirilmesi
}

\author{
Fatma Mutlu SARIGÜZEL1, Çiğdem KARAKÜKCÜ2, Derya KOÇER2, Hatice KARAMAN3, \\ Ahmet KARAMAN4, Ozan YAMAN5, Ahmet GÖDEKMERDAN6 \\ 1 Training and Research Hospital, Clinic of Microbiology, Kayseri, Turkey \\ 2Training and Research Hospital, Clinic of Biochemistry, Kayseri, Turkey \\ 3 Training and Research Hospital, Clinic of Pathology, Kayseri, Turkey \\ 4Training and Research Hospital, Clinic of Gastroenterology, Kayseri, Turkey \\ 5Training and Research Hospital, Clinic of Parasitology, Kayseri, Turkey \\ 6Y.ldirım Beyazıt University Faculty of Medicine, Department of Microbiology-Immunology, Ankara, Turkey
}

\begin{abstract}
Objective: Hepatitis $\mathrm{C}$ virus (HCV) infection is an important cause of chronic liver disease and is associated with oxidative stress. The type of treatment given for chronic HCV infection depends on the genotype of the virus. Genotype $1 \mathrm{~b}$ is known to be associated with poor prognosis, although knowledge about genotype 4 is not sufficient. In this study, we aimed to compare serum paraoxonase (PON1) activities in HCV genotype $1 \mathrm{~b}$-infected patients with those in HCV genotype 4-infected ones, and the relationship of PON1 activity with hepatic damage demonstrated as liver fibrosis. Materials and Methods: In this study, we included 49 patients with HCV genotype $1 \mathrm{~b}$ and 42 with genotype 4 . Serum PON1 activity was analyzed by spectrophotometric method. Serum triglycerides, total cholesterol, LDL, HDL, and transaminases levels and liver histological activity index (HAl) and fibrosis scores were evaluated retrospectively.

Results: Serum PON1 activity was significantly lower in genotype $1 \mathrm{~b}$ compared to that in genotype $4(147.6 \pm 73.9 \mathrm{U} / \mathrm{L}$ and $192.6 \pm 99.0 \mathrm{U} / \mathrm{L}$, respectively; $\mathrm{p}=0.015$ ). There was no significant correlation between PON1 activity and HCV RNA viral load and fibrosis scores ( $p>0.05)$. However, there was no difference in the other serum parameters between the two genotypes $(p>0.05)$. Conclusion: Antioxidant enzyme PON1 activity is lower in genotype 1b compared to that in genotype 4 . This may affect response to therapy and prognosis. Further studies with larger samples are needed to understand the association between PON1 activity and HCV genotypes to elucidate if PON1 activity could be a prognostic factor. Key Words: PON1, HCV, genotype 1b, genotype 4
\end{abstract}

Conflict of interest: The authors reported no conflict of interest related to this article.

\section{ÖZET}

Amaç: Hepatit C virüs (HCV) kronik karaciğer hastalıklarının önemli bir nedenidir ve oksidatif stres ile ilişkilidir. Kronik hepatit C enfeksiyonunda uygulanacak tedavi kişinin enfekte olduğu HCV genotipine bağlıdır. Genotip 1 b'de prognozun kötü olduğu bilinmekle birlikte genotip 4 için yeterli veri bulunmamaktadır. Bu çalışmada, genotip $1 \mathrm{~b}$ ve genotip $4 \mathrm{HCV}$ 'li hastalarda serum paraoksonaz 1 (PON1) aktivitesinin karssılaștırılması ve karaciğer fibrozisi ile gösterilen hepatik hasar ile iliş̧isinin araştıııması amaçlanmıştır. Gereç ve Yöntemler: Bu çalışmaya, $49 \mathrm{HCV}$ genotip 1b ve 42 HCV genotip 4 ile infekte hasta dahil edilmiştir. Serum PON1 aktivitesinin ölçümü spektrofotometrik olarak yapılmıştır. Serum trigliserid, total kolesterol, LDL, HDL, serum transaminaz ve karaciğer histolojik aktivite indeksi (HAl) ve fibrozis skorları retrospektif olarak değerlendirilmiştir.

Bulgular: Serum PON1 aktivitesi, genotip $1 \mathrm{~b}$ ile infekte hastalarda $(147,6 \pm 73,9 \mathrm{U} / \mathrm{L})$ genotip 4 ile enfekte hastalara $(192,6 \pm 99,0 \mathrm{U} / \mathrm{L})$ göre daha anlamlı olarak düsük bulunmustur $(p=0,015)$. Serum PON1 aktivitesi ile HCV RNA viral yük ve fibrozis skorları arasında anlamlı korelasyon bulunmamıştır $(p>0,05)$. Her iki genotipin diğer serum parametreleri arasında istatistiksel olarak anlamlı bir fark olmadığı gösterilmiştir ( $p>0,05)$.

Sonuç: Antioksidan enzim olan PON1 aktivitesi, HCV genotip 1b ile enfekte hastalarda HCV genotip 4 ile enfekte hastalara göre daha düşük olarak saptanmıştır. Bu durum prognozu ve tedaviye cevabı etkileyebilir. PON1 prognostik bir faktör olarak kullanılacaksa HCV genotipleri ile arasındaki ilişkiyi incelemek için daha geniş bir hasta popülasyonunda yapılmış ileri çalışmalara intiyaç vardır. Anahtar Kelimeler: PON1, HCV, genotip 1b, genotip 4

Çıkar çatışması: Yazarlar bu makale ile ilgili olarak herhangi bir çıkar çatışması bildirmemişlerdir. 


\section{Introduction}

Hepatitis $\mathrm{C}$ virus (HCV) infection is a serious infectious condition that may cause chronic liver disease, cirrhosis, and hepatocellular carcinoma in Turkey and in the world, besides, it is associated with oxidative stress (1). Viral and host factors are responsible for the progression of hepatic damage in HCV infection. The various genotypes and subtypes of HCV have been associated with different geographical spread patterns. HCV genotyping is of crucial importance in the determination of the treatment protocols and the follow-up of the clinical course since treatment success rate is low and the duration of treatment is longer in HCV genotype 1-infected patients (2). HCV genotype $1 \mathrm{~b}$ is the most common type in the Central Anatolian Region in Turkey. Indeed, the prevalence of genotype 4 in Kayseri, a city in the Central Anatolia, is higher than the national HCV genotype distribution (3).

In recent years, an imbalance between oxidant production and antioxidant capacity was determined to be implicated in cell destruction (1). HCV is capable of producing high oxidative stress within hepatocytes and also, reactive oxygen species (ROS)mediated liver injury may be triggered by lipid peroxidation $(4,5)$. Paraoxonase-1 (PON1) which is synthesized mainly by the liver is found in the circulation associated with high-density lipoproteins (HDLs) (6). PON1 protects low-density lipoprotein against oxidative modification and prevent LDL oxidation. Due to hydrolyzing lipid function of peroxides in oxidised lipoproteins, human PON1 is recognized as an anti-oxidant enzyme. This function of PON1 can be useful for monitoring of chronic hepatitis disease $(1,7,8)$. In recent studies, it has been reported that serum PON1 may be significantly reduced in patients with chronic liver disease (7, $9,10,11,12)$

In this study, we aimed to compare serum PON1 activities in HCV patients with genotype 1b with those in patients with genotype 4, and the relationship of PON1 activity with hepatic damage demonstrated as liver fibrosis and histological activity index (HAl) scores in fine needle biopsy materials.

\section{Materials and Methods}

\section{Patients}

Hepatitis C virus genotypes were retrospectively evaluated in a total of 91 patients (57 female, 34 male) with chronic hepatitis $\mathrm{C}$ admitted to our hospital. Gender, age, serum triglycerides, total cholesterol, LDL and HDL cholesterol, aspartate aminotransferase (AST), alanine aminotransferase (ALT) levels, HCV RNA viral load, $\mathrm{HAl}$ score and stage of liver fibrosis in all patients were determined. Patients who were admitted our laboratory for analysis of $\mathrm{HCV}$ genotypes for determining the treatment modality and those who did not receive any treatment were selected for this study. Biochemical parameters and HCV RNA titers were studied on samples drawn on the same day with the liver biopsy. The serum was then separated from blood cells by centrifugation and stored at $-80{ }^{\circ} \mathrm{C}$ until PON1 analysis. Forty controls were also analyzed for serum PON1 activity.
Forty healthy subjects were included as control group. All control subjects were HCV RNA-negative and healthy and were evaluated for any symptoms of clinical evidence of chronic diseases (diabetes mellitus, renal disease, cardiovascular disease). None of the control subjects smoked or used alcohol.

\section{Quantification of HCV RNA}

HCV RNA levels were determined by a commercial real time polymerase chain reaction system, the COBAS ${ }^{\circledR}$ AmpliPrep/ COBAS $^{\circledR}$ TaqMan $^{\circledR} 48$ HCV test (ROCHE).

\section{HCV Genotyping}

All HCV RNA-positive samples were subjected to $\mathrm{HCV}$ genotyping by pyrosequencing methods. HCV RNA-positive samples were sequenced by PyroMarkQ24 assay (Qiagen, Germany) following the manufacturer's instructions.

\section{Histopathological Evaluation}

The stage of fibrosis was assessed according to the METAVIR scoring system. Liver fat scores (LFSs) were defined as follows: score for fibrosis (F): F0-no fibrosis; F1-portal fibrosis without septa; F2-portal fibrosis with rare septa; F3-numerous septa without cirrhosis; and F4-cirrhosis.

\section{Measurement of Paraoxonase}

PON1 assays were performed without additional $\mathrm{NaCl}$. PON1 was measured in serum samples collected from the patients. PON1 activity was measured by a fully automated paraoxonase activity measurement kit (Rel Assay Diagnostics ${ }^{\circledR}$ Kit, Turkey). Linear increase of the absorbance of p-nitrophenol, produced from paraoxon, was followed at kinetic measurement mode. Nonenzymatic hydrolysis of paraoxon was subtracted from the total rate of hydrolysis. The molar absorptivity of p-nitrophenol is 18.290 $\mathrm{M}^{-1} \mathrm{~cm}^{-1}$ and one unit of paraoxonase activity is equal to $1 \mu \mathrm{mol}$ of paraoxon hydrolyzed per liter per minute at $37{ }^{\circ} \mathrm{C}$. The reaction was initiated at $37{ }^{\circ} \mathrm{C}$ by the addition of the substrate solution, and using a spectrophotometer (Readwell, India), absorbance was continuously monitored at $405 \mathrm{~nm}$.

\section{Statistical Analysis}

Statistical analyses were performed using SPSS 21.0 (SPSS Inc., Chicago, IL, USA) with $\mathrm{p}<0.05$ as the probability level. The Kolmogorov-Smirnov test was used evaluating the histograms to assess the normality of the data. Values were expressed as frequencies, mean \pm standard deviation according to the type variance and normality. Comparisons of patients and control groups were computed by one-way ANOVA. To compare the differences between genotype $1 \mathrm{~b}$ and genotype 4 for HAl, fibrosis scores and HCV RNA, independent two-sample t-test was performed. In addition, Pearson's correlation analysis was performed for any correlation between PON1 activity and HCV RNA viral load and fibrosis scores.

\section{Results}

The mean PON1 activity in control group $(n=40)$ was $194.5 \pm 36.9$ and in HCV patients ( $n=91)$ was $168.8 \pm 89.5$ ( $p=0.028)$. PON1 activities and demographic data of patients and control group are shown in Table 1. There was no significant difference in total cholesterol, LDL and HDL cholesterol levels between the two 
genotypes and control group ( $p>0.05)$. Besides, no significant difference was observed between two genotypes in $\mathrm{HAl}$, fibrosis scores and HCV RNA viral load. Serum transaminase levels in patient groups were significantly higher than in control group $(p<0.05)$. However, serum PON1 activity was lower in genotype $1 \mathrm{~b}$ compared to that in genotype 4 and control groups (147.6 \pm 73.9

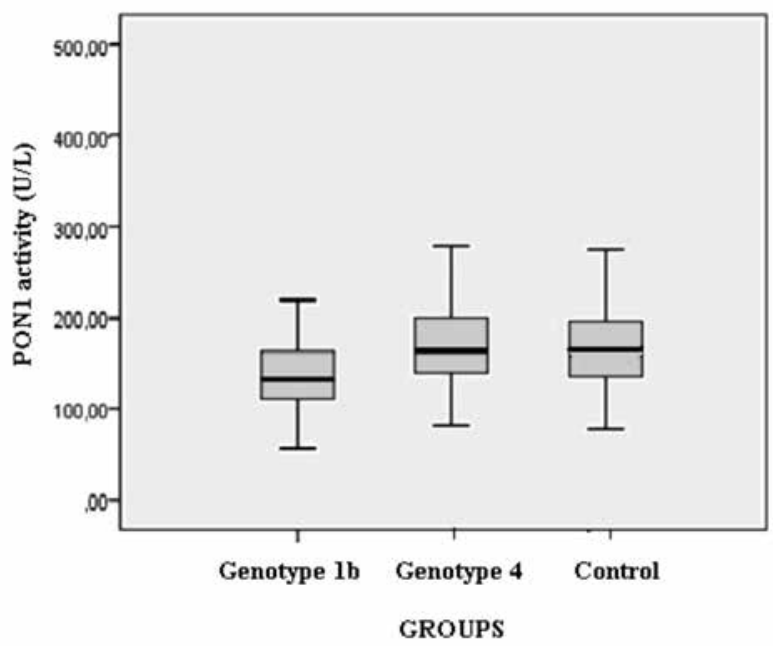

Figure 1. Comparison of serum PON1 activities of genotype $1 b, 4$ and control group. Genotype $1 \mathrm{~b}$ is different from genotype 4 and control group $(p=0.015)$
$U / L, 192.6 \pm 99.0 U / L$ and 194.5 \pm 36.9 , respectively; $p=0.015)$. There was no correlation between PON1 activity and liver enzymes, HCV RNA viral load and fibrosis scores ( $p>0.05)$.

\section{Discussion}

$\mathrm{HCV}$ is capable of producing high oxidative stress in hepatocytes. The defense against oxidative injury is made through antioxidant pathways. Since the antioxidant activity of PON1, which is originated from the liver, was found to be reduced in chronic liver damage, it may be particularly meaningful as an index of liver function status $(7,9)$. It has been previously reported that oxidative stress is increased in patients with chronic liver disease $(7,10,11,12)$.

The most prevalent two HCV genotypes in Kayseri Province in Turkey are $1 \mathrm{~b}$ and 4 (64.7\% and 28.3\%, respectively) (3). Genotype $1 \mathrm{~b}$ is known to have poor prognosis, although knowledge about genotype 4 is not sufficient. Since genotype 4 is the second most common HCV genotype and knowledge about its prognosis is not enough, we compared the antioxidant enzyme levels, serum lipids, liver function tests and fibrosis scores in patients with genotype 4 with those in patients with genotype 1b, the most common HCV genotypes in our region. Therapy in patients infected with $\mathrm{HCV}$ depends on the genotype of the virus. Prognosis and life expectancy in patients with chronic HCV infection depends on how much the liver is damaged and how well a person responds to treatment. Hepatic damage may be due to a direct viral cytopathic effect or an immune-mediated process in patients infected with

\begin{tabular}{|c|c|c|c|}
\hline & $\begin{array}{l}\text { Genotype 1b }(n=49) \\
(\text { mean } \pm \text { SD) }\end{array}$ & $\begin{array}{l}\text { Genotype } 4(n=42) \\
\text { (mean } \pm \text { SD) }\end{array}$ & $\begin{array}{l}\text { Control }(n=40) \\
\text { (mean } \pm \text { SD) }\end{array}$ \\
\hline Age (year) & $60.3 \pm 7.9$ & $63.1 \pm 8.2$ & $59.7 \pm 8.3$ \\
\hline Gender (Female/Male) & $32 / 17$ & $25 / 17$ & $21 / 19$ \\
\hline PON1 activity (U/L) & $147.6 \pm 73.9 \mathrm{a}$ & $192.6 \pm 99.0$ & $194.5 \pm 36.9$ \\
\hline *HAl & $7.42 \pm 1.8$ & $7.17 \pm 1.8$ & - \\
\hline *Fibrosis & $3.3 \pm 1.5$ & $2.9 \pm 1.4$ & - \\
\hline Total cholesterol (mg/dL) & $156.5 \pm 27.1$ & $158.4 \pm 26.8$ & $158.5 \pm 24.1$ \\
\hline LDL cholesterol (mg/dL) & $81.7 \pm 20.8$ & $85.5 \pm 26.4$ & $86.8 \pm 18.1$ \\
\hline HDL cholesterol (mg/dL) & $44.9 \pm 12.7$ & $52.4 \pm 16.3$ & $50.5 \pm 15.1$ \\
\hline Triglyceride (mg/dL) & $129.8 \pm 62.3$ & $102.5 \pm 31.6$ & $105.2 \pm 28.1$ \\
\hline AST (IU/mL) & $55.0 \pm 27.0$ & $47.2 \pm 27.6$ & $23.5 \pm 6.6 \mathrm{~b}$ \\
\hline ALT (IU/mL) & $59.7 \pm 36.4$ & $45.5 \pm 31.2$ & $25.9 \pm 7.1 \mathrm{c}$ \\
\hline${ }^{*} \mathrm{HCV}$ RNA (IU/mL) & $2.99 \pm 86.2 \times 106$ & $4.41 \pm 95.5 \times 106$ & - \\
\hline
\end{tabular}

HAl: Liver histological activity index, LDL: Low density lipoprotein, HDL: High density lipoprotein, AST: Aspartate aminotransferase, ALT: Alanine aminotransferase, p: Differences of three groups were computed by one way ANOVA test.

*: Differences between Genotype 1b and Genotype 4 for HAl, Fibrosis and HCV RNA were performed by independent two-sample t test and no significant difference was observed between groups $(p>0.05)$

a: Genotype $1 \mathrm{~b}$ is different from Genotype 4 and control $(p<0.05)$, b: Control is different from Genotype $1 \mathrm{~b}$ and Genotype 4 ( $<<0.05)$, c: Control is different from Genotype $1 \mathrm{~b}$ and Genotype $4(p<0.05)$ 
chronic hepatitis C. Since patients with low levels of fibrosis respond better to treatment, liver biopsy is of crucial importance in the determination of the treatment modality and response to treatment in patients with chronic hepatitis C. Besides, HCV genotype is considered to be an independent factor affecting the response to interferon therapy (13).

Previously, several studies have reported decreased PON1 activity in infected patients with chronic hepatitis $C(7,10,11,12)$. Ferre et al. (14) investigated PON1 activity and its correlation with oxidative stress, fibrosis and soluble fatty acid synthase in patients with chronic liver diseases. They have suggested an active role of PON1 in the regulation of oxidative stress, fibrosis and hepatic cell apoptosis in chronic liver diseases. There are two theories explaining this situation: Firstly, the decrement in PON1 activity may be the result of hepatic dysfunction. In the present study, we have found that antioxidant enzyme PON1 activity was lower in genotype $1 \mathrm{~b}$ compared to that in genotype 4. However, $\mathrm{HAl}$, fibrosis scores, liver function tests in the two genotypes were similar. Therefore, we can conclude that PON1 activity is lower in genotype $1 \mathrm{~b}$ independently from hepatic damage. The other theory was; PON1 could be decreased as a consequence of changed synthesis and/or secretion of HDL (7). PON1 is a structural enzyme of HDL. In a study, Dirican et al. (15) reported that a reduction in HDL may lower PON1 activity. In this study, although HDL levels were mildly lower in genotype $1 \mathrm{~b}$ than in genotype 4, there was no statistically significant difference between the two genotypes. Thus, the difference between PON1 activities cannot be explained with the degree of fibrosis or HDL levels.

The standard liver function tests (serum ALT, AST levels) are recognized as markers reflecting the degree of the histological damage and they serve as parameters for starting therapy or judging response to antiviral treatment in chronic hepatitis $\mathrm{C}$. However, most studies show conflicting results about the relationship of the degree of histological damage, and serum ALT and AST levels with HCV RNA viral load in chronic hepatitis $C(15,16,17,18)$. In genotype $1 \mathrm{~b}$ and 4 , we also could not find any correlation between liver enzyme levels and viral load. In this study, there was no difference in serum AST and ALT levels between the genotypes.

There are some limitations in our study. It was a retrospective study and some clinical data could not be obtained.

We found that antioxidant enzyme PON1 activity was lower in genotype $1 \mathrm{~b}$ compared to that in genotype 4 , despite similar lipid profile, serum transaminase levels, and $\mathrm{HAl}$ and fibrosis scores. Further studies in larger samples are needed to understand the association of PON1 activity with other antioxidants and HCV genotypes and whether it could be a prognostic factor.

\section{References}

1. Paracha UZ, Fatima K, Alqahtani M, Chaudhary A, Abuzenadah A, Damanhouri G, Qadri I. Oxidative stress and hepatitis $C$ virus. Virol J. 2013;10:251

2. Czepiel J, Biesiada G, Mach T. Viral hepatitis C. Pol Arch Med Wewn. 2008;118:734-740.
3. Mutlu Sarıguzel F, Kayman T, Karaman $H$, Karaman A, Karakukcu C. Distribution of Hepatitis C virus genotypes in the Kayseri region, Turkey: unexpected rate of genotype 4. Clin Lab. http://www.ncbi.nlm.nih.gov/ pubmed/?term =Mutlu+Sar\% C4\%B1 guzel+F\% 2CHCV 2013;59:1403-1438.

4. Beard MR, Jones BE. Hepatitis C virus and oxidative stres: a dangerous liaison. Future Virol. 2006;1:223-232.

5. Olalye MT, Rocha JB. Commonly used tropical medicine plants exhibit distinct in vitro antioxidant activities against hepatotoxins in rat liver. Exp Toxicol Pathol. 2007;58:433-438.

6. La Du BN, Aviram M, Billecke S, Navab M, Primo-Parmo S, Sorenson RC, Standiford TJ. On the physiological role(s) of the paraoxonases. Chem Biol Interact. 1999;119-120:379-388.

7. Kılıc SS, Aydın S, Kılıc N, Erman F, Aydın S, Celik I. Serum arylesterase and paraoxonase activity in patients with chronic hepatitis. World J Gastroenterol. 2005;11:7351-7354.

8. Baskol G, Baskol M, Kocer D. Oxidative stres and antioxidant defense in serum of patients with non-alcoholic steatohepatitis. Clin Biochem. 2007;40:776-780.

9. Ferré N, Camps J, Prats E, Vilella E, Paul A, Figuera L, Joven J. Serum paraoxonase activity: a new additional test fort he improved evaluation of chronic liver damage. Clin Chem. 2002;48:261-268.

10. Aslan M, Horoz M, Nazlıgul Y, Bolukbas C, Bolukbas FF, Selek S, Aksoy N, Erel O. Serum paraoxonase and arylesterase activities for the evaluation of patients with chronic hepatitis. Int $\mathrm{J}$ Clin Pract. 2008;62:1050-1055.

11. Ali EM, Shehata HH, Ali-Labib R, Esmail Zahra LM. Oxidant and antioxidant of arylesterase and paraoxonase as biomarkers in patients with hepatitis C virus. Clin Biochem. 2009;42:13941400.

12. Keskin M, Dolar E, Dirican M, Kiyici M, Yilmaz Y, Gurel S, Nak SG, Erdinc S, Gulten M. Baseline and salt-stimulated paraoxonase and arylesterase activities in patients with chronic liver disease: relation to disease severity. Intern Med J. 2009;39:243-248.

13. Koff RS. Hepatitis C. In: Gorbach SL, Barlett JG, Blacklow NR, eds. Infectious Diseases. 3rd ed. Philadelphia: Lippincott Williams, 2004:779-784.

14. Ferre N, Marsillach J, Camps J, Mackness B, Mackness M, Riu F, Coll B, Tous M, Joven J.

15. Dirican M, Akca R, Sarandol E, Dilek K. Serum paraoxonase activity in uremic predialysis and hemodialysis patients. J Nephrol. 2004;17:813-818.

16. Gretch D, Corey L, Wilson J, dela Rosa C, Willson R, Carithers R Jr, Busch M, Hart J, Sayers M, Han J. Assessment of hepatitis $C$ virus RNA levels by quantitative competitive RNA polymerase chain reaction: high-titer viremia correlates with advanced stage of disease. J Infect Dis. 1994;169:1219-1225.

17. Filipak CL, Gordon SC, Silverman AL. Liver histology and hepatitis $C$ RNA levels in patients with hepatitis $C$ and normal or near normal aminotransferase values. Am J Gastroenterol. 1994;89:1671-1675.

18. Haber MM, West $A B$, Haber $A D$, Reuben $A$. Relationship of aminotransferases to liver histological status in chronic hepatitis C. Am J Gastroenterol. 1995;90:1250-1257. 